\section{Education for Readers' Advisory Service in Library and Information Science Programs Challenges and Opportunities}

\section{Connie Van Fleet, Guest Columnist}

Correspondence concerning this column should be addressed to Barry Trott, Adult Services Director, Williamsburg Regional Library, 7770 Croaker Rd., Williamsburg, VA 23188; e-mail:btrott@mail.wrl.org.

Connie Van Fleet is Professor, School of Library and Information Studies, University of Oklahoma, Norman.
Most frequently, this column looks at potential new directions in readers' advisory theory and practice, offering tools that readers' advisors can use in their day to day work as well as expanding the theoretical foundations of that practice. This issue, we step back and take a broader view, looking at the challenges and opportunities that arise in making readers' advisory services an integral part of library-school education. Connie Van Fleet is a professor at the School of Library and Information Studies at the University of Oklahoma. One of her major fields of research is the "interaction of practitioners and educators in the library and information science professions." She also has a strong interest in readers' advisory work, and is coauthor of African-American Literature: A Guide to Reading Interests (Libraries Unlimited, 2004). In this column, Van Fleet makes a strong case for the importance of readers' advisory studies in the curriculum of library and information studies programs, and suggests where both library educators and library practitioners can collaborate more actively to develop a strong foundation of readers' advisory theory and practice.-Editor

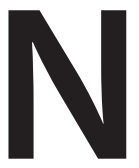

o one who keeps abreast of current trends in libraries and information science can doubt that readers' advisory is an important service area that is expanding its conceptual base and growing in practice. This is an area of education that is rich in the use of experiential learning pedagogies, critical analysis, and interdisciplinary foundations. Nevertheless, there are special challenges, as well as opportunities, in teaching readers' advisory. Although individual programs may offer excellent courses of study that prepare librarians to meet the needs of readers, marginalization of this area in schools of library and information studies persists. But the trends of the past several years give rise to cautious optimism.

Two columns that appeared in the winter 2000 issue of RUSQ provide an excellent springboard for a discussion of current issues of education for readers' advisory. "Time to Turn the Page: Library Education for Readers' Advisory Services" by Dana Watson and the RUSA CODES Readers' Advisory Committee examined the content and availability of readers' advisory-related courses in ALA-accredited programs. ${ }^{1}$ Duncan Smith contributed "Talking with Readers: A Competency Based Approach to Readers' Advisory Service," the first offering in the Readers' Advisory column, which Danny P. Wallace and I created when we assumed editorship of RUSQ. ${ }^{2}$ 


\section{CONTENT AND METHODS OF READERS' ADVISORY COURSES}

The content of readers' advisory services (and courses) has expanded as we (the readers' advisory community) explored what actually happens in libraries and found out more about what people want to read. We have moved from offering only genre fiction guidance to offering guidance for leisure reading, including mainstream fiction and nonfiction titles. For teachers of readers' advisory, life has never been so good. We have an expanded research base and a growing number of resources to support our work. We enjoy active and enthusiastic partnerships with intelligent, lively, and creative librarians.

As Burgin and Shearer point out, readers' advisory courses that are considered integral to the curriculum are most often associated with individual faculty. ${ }^{3}$ Perhaps this accounts for the enthusiasm for the course that is evident in most syllabi. In any event, these courses reflect the nature of education for a profession, combining a conceptual framework with practical applications. Almost all readers' advisory courses in MLIS programs are designed to address three levels of learning: knowledge, basic skills and techniques, and attitude.

Faculty usually ground courses in interdisciplinary research, addressing such topics as motivations for and the impact of reading, the social nature of reading, and cultural contexts and implications of stories. Studies of various types of literature (genre, mainstream fiction, and nonfiction) extend beyond familiarity and appeal factors to analysis of underlying themes and literary criticism.

These underlying theories and analyses serve as the foundation for the basic readers' advisory skill set. Duncan Smith, using a "practice audit" approach to model development in which librarians observed taped interviews of librarians and readers, identifies four areas of competencies: (1) background in fiction and nonfiction, (2) understanding people as readers and readers as people, (3) the appeal of books, and (4) the readers' advisory transaction. ${ }^{4}$ These are congruent with the outlines of basic texts frequently used in readers' advisory courses: Saricks's classic Readers Advisory Service in the Public Library; Genreflecting, the book whose original publication in 1982 is often credited as the impetus for the readers' advisory revolution, Saricks's Readers' Advisory Guide to Genre Fiction, and Burgin and Shearer's The Readers' Advisor's Companion. ${ }^{5}$

Readers' advisory courses in MLIS programs all address skills for professional practice. Typically, students read in a variety of genres (both fiction and nonfiction), identify appeal factors, and write annotations that demonstrate that ability. Courses, whether face to face or online, generally include opportunities for students to practice talking with colleagues about books. Students may present booktalks, give presentations, create readers' advisory tools or develop awareness materials such as bookmarks, brochures, or Web sites. Most will learn to guide a book discussion.

Reflecting the close association of readers' advisory education with practice, most readers' advisory courses include assignments that require students to interact directly with readers or readers' advisors. These may include unobtrusive observations, in which students act as patrons and ask questions of librarians, or shadowing activities, in which students interview readers' advisors or observe them in action. In some courses, students may interview readers to determine how they think about the reading experience. In my own courses, students conduct a readers' advisory interview, select materials for the reader, and conduct a second interview to get the reader's reaction to their selections. They then analyze the exchange to determine what was effective and what aspects of the process they would change.

The growing number of resources is another exciting element of readers' advisory service. There are a number of fine print sources that are useful to readers' advisors and enjoyable to readers. The Genreflecting Series, for instance, now includes entries devoted to mainstream and nonfiction materials, as well as those focused on special audiences. In addition to several excellent subscription databases (NoveList from EBSCO, The Online Readers' Advisor from Libraries Unlimited, among others), there are myriad Web sites to support reading guidance. Despite this, the literature suggests that librarians tend to rely on personal knowledge rather than use readers' advisory sources. ${ }^{6}$ Readers' advisory courses require students to become familiar with a variety of sources, both print and online. Most require comparison and critical analysis of several sources, a practice that not only enhances the students' working knowledge of the specific sources but also instills a critical approach that will serve them throughout their professional careers.

\section{ISSUES AND CHALLENGES IN TEACHING READERS' ADVISORY}

\section{Grounding Readers' Advisory in Reference}

One indication of growing attention to readers' advisory is the increased attention it is given in basic reference textbooksBopp and Smith's Reference and Information Services: An Introduction includes a brief discussion in a section on "Interviews for Specific Situations."7 Ross, Nilsen, and Dewdney's Conducting the Reference Interview provides a more developed introduction, and Cassell and Hiremath's Reference and Information Services in the 21st Century includes an entire chapter on "Reader's Advisory Work." "These discussions all serve to introduce readers' advisory service to a broader audience of students. This is an especially positive development when programs offer second level electives in readers' advisory that allow students to pursue interests that have been piqued by these brief introductions. There is, however, the possibility of an unintended consequence. If readers' advisory service is seen merely as an add-on to basic reference that can be "covered" in a single class session, we have unintentionally undermined the unique conceptual framework, processes, and goals of readers' advisory service. 


\section{READERS' ADVISORY}

\section{Incidental Information Acquisition, Accidental Learning, and Nonfiction Leisure Reading}

Readers' advisory service in the past twenty-five years has grown from an almost exclusive focus on genre fiction to include all forms of leisure reading. The inclusion of nonfiction in the catalog of items that readers choose certainly reflects practice and has been documented in the literature. ${ }^{9}$ Research into the nature and motivation for reading fiction has always included the concept of fiction as educational, and recent studies of fiction readers have explored "incidental information acquisition." 10 These aspects enrich readers' advisory service and more completely and accurately reflect the activities of leisure readers.

The challenge here is to avoid the temptation to justify fiction or readers' advisory in terms of purposeful reading or to unintentionally reinforce a hierarchy that values nonfiction reading or information acquisition more highly than other forms of leisure reading. Wiegand, attempting to explain the move of library and information curricula from reading to information, explores the growth of the concepts of "work" and "leisure" and the role of commoditization of information. ${ }^{11}$ Chelton calls this the "entertainment vs. information" false dichotomy. ${ }^{12}$ However it is expressed, it implies that reading for fun, for escape, or for pure pleasure is not the same as, is not as valuable as, and does not overlap with nonfiction reading or fiction reading that results in some information acquisition.

\section{Attitude Adjustment}

Students new to readers' advisory may be avid readerswith decided prejudices. It is not so much that they ascribe to the hierarchy of information over entertainment or useful reading as opposed to recreational reading. It is simply that they have learned to judge books in terms of objective literary standards rather than subjective individual tastethe "good book" vs. "good literature" dichotomy. One of the most difficult challenges is to get students to look at books' appeal to readers and to speak in positive (or at least objective) terms of books that they do not personally enjoy. Some students, in fact, are resistant to genre reading at all and, until actually assigned, have never read a romance or a western. These students may retain their personal preferences, but after exploring the appeal of themes and archetypes within genres to various audiences, they come to understand the value of these books and the professional's role in identifying them for readers. In addition to students who merely choose not to read certain genres are those who may not be able to deal with certain themes (sexual abuse, violence) or types of literature (horror). Individual accommodations are generally made for these students, but they nevertheless must learn to use tools in an effective way so they can offer professional service to readers. It is only when students understand that their personal preferences are no more valid in readers' advisory service than their political (or religious) affiliations are in providing reference service that they can hope to provide effective guidance.

\section{Coping with Ambiguity}

As Saricks has pointed out, students may be overwhelmed by the multiplicity of factors involved in selecting a good book. ${ }^{13}$ If working from multiple appeal factors can be overwhelming, how must an inexperienced readers' advisor feel when confronted with Neal Wyatt's (admittedly intriguing) "Whole Collection Readers' Advisory Service" and its articulation as "reading map"? ${ }^{14}$ How do you teach someone to cope with the notion of offering suggestions rather than providing "correct" answers?

\section{Instilling a Lifelong Learning Attitude}

One aspect of the development of professionals is the need to instill a lifelong learning attitude and a commitment to continuous professional education. For degreed librarians, this attitude is especially important because they will serve as role models for those whom they will supervise. Readers' advisory courses present a number of strategies to accomplish this: introducing students to the professional literature through assigned readings and papers; engaging them in professional networks such as Fiction_L; or encouraging attendance at professional conferences. In some courses, students will keep a personal reading log. In others, they will develop a reading plan for continued professional development beyond graduation.

\section{Research}

Readers' advisory builds on a rich, interdisciplinary research base. We know that leisure reading affects people in many ways: intellectually, psychologically, emotionally, even physically. ${ }^{15}$ Yet we still seem to know more about readers as readers than about providing effective library service to them. Moyers' study of readers' advisory literature since 1995 finds that much of the research literature is published abroad and may be affected by cultural referants. ${ }^{16}$

Many studies of readers' advisory services have been based on data gathered by MLIS students posing as library patrons. Our theories of adult behaviors may be based on research using MLIS students and reports may equate student reactions with those of the general public. In fact, we are not as fastidious about distinguishing students from other research subjects as we could be, nor do we often discuss the possible limitations the use of student surrogates might place on the meaning or application of our findings. It is appropriate to give assignments in which our students learn to empathize with their future patrons by acting in their roles. Our students can provide informed observations of librarian behavior; they can act as data-gatherers in the field. But as research on the reference interview has moved from studying librarian behavior to understanding user needs and communication patterns, use of student surrogates is declining. 
Much of our practice is based on anecdotal evidence and observation of best practice rather than on empirical method. We have all benefited from Sharon Baker's work on genre classification and arrangement. ${ }^{17}$ It would be useful to test some of the innovative readers' advisory practices that have been proposed: Does welcoming signage increase readers' advisory questions? ${ }^{18}$ Does a readers' advisory form increase effectiveness? ${ }^{19}$ Do "reading maps" as suggested by Neal Wyatt result in more effective reader guidance? ${ }^{20}$

While all of these issues are certainly legitimate, perhaps the greatest challenges of all are related not to what we offer in readers' advisory courses, but whether or not education for readers' advisory is a part of the MLIS curriculum at all.

\section{READERS' ADVISORY COURSES IN MLIS PROGRAMS}

When Watson and CODES solicited information and syllabi related to readers' advisory courses from the fifty-six ALAaccredited MLIS programs, only fourteen schools identified such offerings. ${ }^{21}$ Shearer and Burgin received thirty-four responses to a 1999 survey of readers' advisory coverage in ALA-accredited programs in the United States and found that the majority of respondents gave attention to readers' advisory principles and techniques in elective course, but few included them in core courses that introduced students to the theoretical foundations to the field. ${ }^{22}$

My sense that readers' advisory offerings have grown in number is reinforced by a survey of the MLIS course descriptions found on the Web sites of the accredited programs (excluding Montreal and Puerto Rico). My analysis suggested that twenty-eight of the schools currently offer relevant courses (one school is included twice in the following breakdown). Six schools offered courses with the term "readers' advisory" in the title, and another eight schools had courses on "reading" or "reading interests." Fifteen of sixteen "adult services" courses included descriptions that explicitly or implicitly suggested attention to readers' advisory services. The difference in numbers may be due to the different methodologies or an actual increase in related course offerings. Of those courses for which format could be determined, five were offered through distance education formats. All of the courses that listed dates have been offered within the past year or will be offered in the spring 2008 semester.

Nevertheless, it appears that about half of the MLIS programs offer courses that teach students about readers' advisory. While this is certainly a marked increase from the $25 \%$ or so reported in 1999, it is still a figure that gives rise to the theme that traditionally appears in discussions of readers' advisory: why is readers' advisory not more widely taught in schools of library and information science?

\section{Instructors of RA Courses}

Full-time faculty members (and one emerita) were listed as instructors of record for 9 of the courses, as were 6 adjuncts and one visiting professor. No instructor was listed for 12 of the courses. An analysis of LIS faculty positions advertised from July 2006 through October 2007 on JESSE, a discussion list for library and information science educators, found that of 35 listings, expertise was sought to fill positions in the following areas: youth services (6 positions), digital libraries (6), technology (5), technical services (4), school library media centers (3), academic libraries (2), archives (2), health information (2), reference (2), information architecture (2), research methods (1), information science (1), information security (1), and readers' advisory (1). The opening for readers' advisory was the only advertisement for a part-time instructor to teach the course, which is being offered online.

Students who are engaged and excited by the theories and concepts to which they are introduced in readers' advisory or adult services classes and who decide to pursue doctorates may find that they are hard-pressed to find a doctoral program in a school of library and information science that meshes well with their intended area of study and research. At a time when we are desperately recruiting the next generation of library and information science educators, we are often driving students from our doctoral programs in library and information studies to cognate disciplines, such as adult education, reading, literary criticism, communication, popular culture, or media studies, where they can pursue their interests. Some of these leave with every intention of returning to teach in a school of library and information science; some never do.

When preparing for this article, I took advantage of opportunities to meet with others whom I know to be committed to readers' advisory service. I explained that I was going to write a piece on issues and challenges. I was surprised when the first issue that arose was the use of adjunct faculty to teach readers' advisory courses in a number of schools. I was taken aback because the comments came from outstanding librarians who actually teach these courses. When I asked why they thought this was a problem, it became clear that they were not concerned about the quality of the courses, but felt that use of an adjunct signaled that the course was not considered integral to the curriculum, that assignment to an adjunct, no matter how qualified, implied a lower value for that course, and that without an advocate on the full-time faculty, the courses might disappear at a whim. Use of adjuncts to teach specialized courses is a growing practice in LIS education, and the Standards for Accreditation approve of this practice. Standard III Faculty states: "Particularly in the teaching of specialties that are not represented in the expertise of the fulltime faculty, part-time faculty enrich the quality and diversity of a program." On the other hand, Standard III also stipulates that "Full-time faculty members are qualified for appointment to the graduate faculty within the parent institution and are sufficient in number and in diversity of specialties to carry out the major share of the teaching, research, and service activities required for a program, wherever and however delivered." ${ }^{23}$ Many educators are concerned that adjuncts are not fully integrated into the academic endeavor and are not 


\section{READERS' ADVISORY}

given sufficient support and guidance. The Association for Library and Information Science Education has observed this trend and in the past year has undertaken several initiatives to recognize the contributions and needs of librarians who teach in MLIS programs.

A theme that traditionally appears in discussions of readers' advisory is the apparent lack of value attached to it in MLIS education. Among reasons advanced for the apparent dearth of readers' advisory-related courses are the ascendance of information as commodity; a fascination with technology as subject, rather than tool; failure to appreciate the interdisciplinary grounding and rigorous research that underpins reading; the value of story; association with public and school libraries; and appearance of fun. ${ }^{24}$ These discussions appear elsewhere. I will suggest a few others.

\section{Perceptions of Training and Education}

Readers' advisory has been given impetus from the field. Practicing librarians are among the strongest advocates for excellence in service and are responsible for creating many of the tools and resources that are used to support readers' advisory training. This may be one of the reasons that more schools do not offer readers' advisory or do not consider it the intellectual equivalent of other courses. We have somehow come to regard readers' advisory as a branch of reference that can easily be grafted to the basics of reference, rather than an area of expertise and investigation in its own right.

In the article I alluded to earlier, Smith points out that models of service, supported by research, exist, but are not implemented in practice. He concludes "If staffs are to do better at providing readers' advisory service, librarianship must find a way of moving these models from print into practice." Further, he says "Continuing education and staff development are two strategies used to address these needs. . . First, the profession needs to identify and define the nature of the readers' advisory role. Library staff members need a map of readers' advisory practice. Secondly, a means of transmitting this map to practitioners is needed so that they can change the way they provide readers' advisory service." 25 Because we have excellent training programs and continuing education activities, the academy has, in many cases, perceived of readers' advisory as just that: a technical skill that can be gained in the workplace.

MLIS programs frame their responsibilities and goals in terms of education. Education tends to focus on general principles and applications to practice and is oriented toward the long term. Training focuses on the skills and techniques needed to solve immediate problems. As noted above, the four areas of readers' advisory competencies Smith identifies are reflected in all readers' advisory courses. But the individual competencies that are listed are very straightforward and skills-based. ${ }^{26}$ If readers' advisory courses are to gain greater credence in LIS programs, the conceptual and research-based underpinnings must be acknowledged and emphasized. Certainly, Smith has contributed to this literature, as have several others who have been at the forefront of the resurgence of readers' advisory services. Yet we constantly hear the phrase "training for readers' advisory" and much of the literature is for staff training and continuing professional education. I do not mean to suggest that continuing education and staff training are unimportant and should not be pursued, merely that the role of MLIS programs is education, not training, and arguments for inclusion of readers' advisory courses will be more effective if not framed in terms of training and skills.

\section{Time Pressures}

Many LIS programs find that they are trying to include too much in too short a time. With a growing knowledge base, smaller faculties, and programs limited to as few as thirty-six hours (twelve courses), many programs are pushed to capacity and can offer few opportunities for specialization. Further, readers' advisory courses may be quite intense for faculty, as they are frequently very popular and usually require a fairly significant workload. In particular, online courses that encourage chat as a means of talking about books can be overwhelming. One faculty member reported that her student's comments on the discussion board often were longer than the assigned books.

\section{(Lack of) Demand from the Field}

While we often deplore the perceived lack of appreciation in MLIS programs, it appears that this only mirrors observations about the lesser value placed on leisure reading by librarians in the field. While some employers, as some educators, place high value on readers' advisory services and education, this is not true of all librarians. Library directors have demonstrated an increased preference for beginning librarians who are technologically savvy and management ready. Mary K. Chelton (never one to mince words) asserts that

public librarians understand readers and their uses of and gratifications from reading rather poorly ... [they] seem to have moved from their nineteenth-century view of actively demeaning "sensational fiction" to a posture of chronic devaluation of books and related media that present occasions for narrative experiences. ... Public librarians now say that public libraries are about "information," but consistently deny knowledge of or the will to act on the knowledge of the possibility for social and self-information contained in narrative stories. ${ }^{27}$

\section{Process-Based Standards}

The ALA "Standards for Accreditation" are qualitative, not quantitative, and are process-driven rather than prescriptive. ${ }^{28}$ Each school must develop its own goals and objectives based on the foundations of the field and ongoing planning processes. This allows for considerable variation in the spe- 
cific ways in which the standards are addressed. Schools that do not choose to emphasize public library service would not logically give much attention to readers' advisory services, just as some schools do not offer courses in health informatics or law librarianship.

\section{SUGGESTED STRATEGIES FOR PROMOTING READERS' ADVISORY IN MLIS PROGRAMS}

Consideration of the issues discussed above suggests several strategies and avenues for promoting readers' advisory in MLIS programs. If there is indeed demand from the field for more attention to readers' advisory, it should be made known. The RUSA CODES Readers' Advisory Committee or PLA can develop standards and guidelines to articulate expectations for service and to guide education. Standard II Curriculum of the Standards for Accreditation states that "The design of specialized learning experiences takes into account the statements of knowledge and competencies developed by relevant professional organizations." ${ }^{29}$ Employers (library directors) can voice their demand for expertise in readers' advisory service by serving on schools' advisory committees and by offering input. Both Standard I Mission, Goals and Objectives, and Standard II Curriculum state that evaluation involves "those served by the program: students, faculty, employers, alumni, and other constituents." 30

Individuals can continue to contribute to the conversation through publication and engagement in association activities. The truly dedicated may volunteer to serve on a committee on accreditation external review panel. Those who can may choose to submit a proposal for teaching a readers' advisory course or offer to guest lecture. Others may offer their libraries as laboratories for teaching and research.

\section{CONCLUSION}

A growing body of research, resource materials, reflective practice, and creative pedagogies will sustain the readers' advisory renaissance. Although there are challenges in practice and in education that should be addressed, readers' advisory service is an exciting and expanding field that brings together librarians, educators, and researchers in their commitment to connect readers with the stories that enrich their lives and our world.

\section{References and Notes}

1. Dana Watson and the RUSA CODES Readers' Advisory Committee, "Time to Turn the Page: Library Education for Readers' Advisory Services," Reference \& User Services Quarterly 40, no. 2 (Winter 2000): 143-46.

2. Duncan Smith, "Talking with Readers: A Competency Based Approach to Readers' Advisory Service," Reference \& User Services Quarterly 40, no. 2 (Winter 2000): 135-42.

3. Kenneth D. Shearer and Robert Burgin, "Partly Out of Sight; Not Much in Mind: Master's Level Education for Adult Readers' Advisory Services," The Readers' Advisor's Companion, ed. Kenneth D. Shearer and Robert Burgin, (Englewood, Colo.: Libraries Unlimited, 2001), 23.

4. Smith, "Talking with Readers," 138.
5. The latest editions of these works are listed here: Joyce Saricks, Readers' Advisory Service in the Public Library, 3rd ed. (Chicago, ALA, 2005); Diana Tixier Herald, Genreflecting: A Guide to Reading Interests in Genre Fiction, 6thed., ed. Wayne Wiegand, (Englewood, Colo.: Libraries Unlimited, 2006); Joyce Saricks, Readers' Advisory Guide to Genre Fiction (Chicago: ALA, 2001); Shearer and Burgin, The Readers' Advisor's Companion.

6. Anne K. May, Elizabeth Olesh, and Anne Weinlich Miltenberg, "A Look at Readers' Advisory Services," Library Journal 125, no. 15 (September 5, 2000): 40-43.

7. Richard E. Bopp and Linda C. Smith, Reference and Information Services: An Introduction, 3rd ed. (Englewood, Colo.: Libraries Unlimited, 2001).

8. Catherine Sheldrick Ross, Kirsti Nilsen, and Patricia Dewdney, Conducting the Reference Interview: A How-to-Do-It Manual for Librarians (New York: Neal-Schuman, 2002); Kay Ann Cassell and Uma Hiremath, Reference and Information Services in the 21st Century: An Introduction (New York: Neal-Schuman, 2004).

9. For example, Jessica Moyer, "Learning from Leisure Reading: A Study of Adult Public Library Patrons," Reference \& User Services Quarterly 46, no. 4 (Summer 2007): 66-79.

10. Catherine Ross, "Finding Without Seeking: The Information Encounter in the Context of Reading for Pleasure," Information Processing and Management 35 (November 1999): 783-99.

11. Wayne Wiegand, "Missing the Real Story: Where Library and Information Science Fails the Library Profession," The Readers' Advisor's Companion, ed. Kenneth D. Shearer and Robert Burgin, (Englewood, Colo.: Libraries Unlimited, 2001), 9-10.

12. Mary K. Chelton, "Reader's Advisory Work," in Cassell and Hiremath, Reference and Information Services in the 21st Century: An Introduction (New York: Neal-Schuman, 2004), 254.

13. Saricks, Readers' Advisory Service, 74-84.

14. Neal Wyatt, "Reading Maps Remake RA," Library Journal 131, no. 18 (Nov 1, 2006): 38-42.

15. For a good overview of reading research, see Catherine Sheldrick Ross, Lynne McKechnie, and Paulette M. Rothbauer, Reading Matters: What the Research Reveals about Reading, Libraries, and Community (Westport, Conn.: Libraries Unlimited, 2006); Wayne Wiegand, "On the Social Nature of Reading," in Herald, Genreflecting, offers an interdisciplinary overview on social aspects of reading.

16. Jessica E. Moyer, "Adult Fiction Reading: A Literature Review of Readers' Advisory Services, Adult Fiction Librarianship, and Fiction Readers," Reference \& User Services Quarterly 44, no. 3 (Spring 2005): 220-31.

17. Sharon L. Baker and Karen L. Wallace, The Responsive Public Library: How to Develop and Market a Winning Collection, 2nd ed. (Englewood, Colo.: Libraries Unlimited, 2002).

18. Saricks, Readers' Advisory Service in the Public Library, 137.

19. Neil Hollands, "Improving the Model for Interactive Readers' Advisory Service," Reference \& User Services Quarterly 45, no. 3 (Spring 2006): 205-12.

20. Wyatt, "Reading Maps Remake RA."

21. Watson, "Time to Turn the Page."

22. Shearer and Burgin, The Readers' Advisor's Companion.

23. American Library Association, Standards for Accreditation of Master's Programs in Library and Information Studies 1992 (Chicago: American Library Association, 1992) www.ala.org/ala/ accreditation/accredstandards.

24. Wiegand, "Missing the Real Story;" Watson, "Time to Turn the Page."

25. Smith, "Talking with Readers," 137

26. Ibid., 138-139.

27. Chelton, "Reader's Advisory Work," 99.

28. American Library Association, Standards for Accreditation.

29. Ibid.

30. Ibid. 